\title{
ПЕДАГОГИЧЕСКОЕ МАСТЕРСТВО ПРЕПОДАВАТЕЛЯ В УЧЕБНОМ ПРОЦЕССЕ НА ОСНОВЕ КОМПЛЕКСНОГО АНАЛИЗА ОБРАЗОВАТЕЛЬНЫХ ТЕХНОЛОГИЙ
}

Бабаева 3. С., старший преподаватель кафедры русского языка и методики преподавания Ташкентский государственный педагогический университет, Узбекистан

DOI: https://doi.org/10.31435/rsglobal_ijitss/31082019/6616

ARTICLE INFO

Received 14 June 2019

Accepted 17 August 2019

Published 31 August 2019

\section{KEYWORDS}

methods, educational technology, pedagogical imagination, pedagogical skills, pedagogical tact, teaching aids, educational process.

\begin{abstract}
The article raises the problem of assessing the level of pedagogical skills of the teacher. According to the author, each teacher can make to the existing educational technology of teaching students of a certain discipline their own scientifically based necessary corrections on the results achieved, which are specific changes that have occurred not only with the students themselves, but also in relations between students and the teacher.
\end{abstract}

Citation: Бабаева 3. С. (2019) Pedagogicheskoe Masterstvo Prepodavatelya v Uchebnom Processe na Osnove Kompleksnogo Analiza Obrazovatel'nyh Tekhnologij. International Journal of Innovative Technologies in Social Science. 5(17). doi: 10.31435/rsglobal_ijitss/31082019/6616

Copyright: (C) 2019 Бабаева 3. С. This is an open-access article distributed under the terms of the Creative Commons Attribution License (CC BY). The use, distribution or reproduction in other forums is permitted, provided the original author(s) or licensor are credited and that the original publication in this journal is cited, in accordance with accepted academic practice. No use, distribution or reproduction is permitted which does not comply with these terms.

Сегодня существует мнение, что педагогическая наука представляет собой определённый вид искусства. Однако искусство посильно далеко не каждому человеку, а лишь тому мастеру, который владеет своим делом, и обладающему определёнными навыками и способностями. К сожалению, не все современные преподаватели способны обладать необходимым педагогическим мастерством, но, тем не менее, каждый способен овладевать педагогическими технологиями. Таким образом, овладеть педагогической наукой - значит стать отличным преподавателем, ведь «хорошая, научно обоснованная технология обучения и воспитания - это и есть педагогическое мастерство» [1, с.52].

Как мы можем видеть, образовательная технология тесно взаимосвязана с таким умением преподавателя как педагогическое мастерство. А совершенное владение образовательной технологией и есть то искомое педагогическое мастерство. Кроме того, педагогическое мастерство, является высшим уровнем владения образовательной технологией, при этом, не ограничиваясь только операционным компонентом. И одна и та же технология спокойно может осуществляться разными преподавателями, с проявлением у них профессионализма и педагогического мастерства, основанного на реализуемой технологии обучения.

Однако вправе задаваться вопросом о том, что же собой представляет искомая нами научно обоснованная технология обучения? В данном случае отвечаем, что:

- во-первых, технология обучения построена на научно-теоретическом анализе деятельности студентов - будущих специалистов, с отбором тех знаний, умений и навыков, которые будут им необходимы в их профессиональной деятельности; 
- во-вторых, анализ и чёткий отбор учебной информации, а именно содержание учебнометодического материала, предназначенного для обучения студентов с контролем его усвоения;

- в-третьих, анализ средств педагогической коммуникации, а именно - учебники, учебные пособия и методические указания к ним;

- в-четвёртых, выбор специальных форм, методов и средств обучения, воспитания и развития студентов с конкретизацией деятельности, как преподавателя, так и студентов.

Сегодня также очень важным моментом является и то, чтобы каждый преподаватель смог вносить в существующую образовательную технологию обучения студентов определённой дисциплины свои научно-обоснованные необходимые коррективы, которые должны зависеть:

- от набора студентов в вузе;

- учёта психологических особенностей студентов;

- развития соответствующей науки (принцип культуросообразности);

- образовательной подготовленности студентов, учитывая требования времени.

Сегодня образовательную технологию можем понимать как последовательную и взаимосвязанную систему действий преподавателя, которые направлены на решение определённых педагогических задач, с планомерным и последовательным воплощением в учебной практике заранее спроектированных педагогических процессов. Данное представление об образовательной технологии предполагает следующие возможности:

- возможность разрабатывать различные выверенные образовательные технологии специалистами, которые имеют достаточно высокий уровень теоретической подготовки при наличии богатого практического опыта;

- возможность иметь свободный выбор образовательных технологий в соответствии с поставленными целями и задачами, имеющимися возможностями и условиями взаимосвязанной учебной деятельности преподавателя и студентов.

В отношении педагогического такта хотелось бы отметить то, что он во многом может зависеть от личных качеств самого преподавателя, его культуры, кругозора, гражданской позиции, силы воли, и, конечно же - профессионального педагогического мастерства. Педагогический такт является именно той основой, на которой строится духовная близость между преподавателями и студентами, зарождается и крепнет их доверие. Кроме того, особенно отчётливо педагогический такт может проявляться в контрольно-результативной, оценочной деятельности преподавателя, где особенно важна непредвзятая внимательность и абсолютная справедливость. Важно отметить, что проявление педагогического такта преподавателем изо дня в день поднимает его авторитет в глазах его коллег и студентов.

В отношении педагогического мастерства, как описывается в книге В.А. Сластёнина, известный педагог А.С. Макаренко неоднократно утверждал то, «что ученики простят своим учителям и строгость, и сухость, и даже придирчивость, но не простят плохого знания дела. Выше всего они ценят в педагоге уверенное и чёткое знание, умение, искусство, золотые руки, немногословие, постоянную готовность к работе, ясную мысль, знание воспитательного процесса, воспитательное умение» [4, с.498]. Более того, А.С. Макаренко «на личном опыте пришёл к убеждению, что решает вопрос мастерство, основанное на умении, на квалификации» [там же с. 498]

В.А. Сластёнин также приводит определённую классификацию умений преподавателя, связанную, прежде всего, «в соотношении теоретической и практической деятельности, демонстрируя её следующим образом:

- умение соотносить теоретическое содержание учебного процесса с конкретными педагогическими задачами, которые необходимо решить педагогу в процессе своей профессиональной деятельности;

- умение применять на практике имеющиеся знания, приводя тем самым в последовательное движение весь педагогический процесс; же c. 42]

- умение понимать сложные взаимосвязи компонентов педагогического процесса» [там

Профессиональное мастерство будет выявляться в том преподавателе, который способен опираться в своей профессиональной деятельности на научно подтверждённые теоретические данные. Естественно, что при всём этом педагог встречается с рядом определённых трудностей:

- во-первых, научная теория является упорядоченной совокупностью общих законов, правил и принципов, а педагогическая практика является всегда ситуативной. Таким образом, 
использование теории в практической деятельности требует уже специфичных навыков теоретического профессионального мышления, которых у преподавателя порой просто не существует;

- во-вторых, педагогическая деятельность является целостным процессом, с опорой на синтез определённых знаний, связанных с философией, психологией, педагогикой, тогда как профессиональные знания самого преподавателя зачастую могут быть не доведены до необходимого уровня обобщённых умений и навыков, которые необходимые для управления образовательным процессом. Это может привести к тому, что преподаватели часто начинают овладевать педагогическими умениями не благодаря влиянию научной теории, а уже независимо от неё, основываясь на житейских, обыденных представлениях о педагогической деятельности.

Российский психолог А.А. Бодалев определяет в своём исследовании педагогическое мастерство посредством понятия «педагогическое воображение», которое «заключается в умении учителя поставить себя на место ученика и в соответствии с этим строить свою работу» [2, с. 69] Педагогическое мастерство должно зависеть и от гражданской позиции самого преподавателя, особенно от его личностно-деловых качеств, сформированности его профессионального самосознания с профессионально-ценностном отношением к самому себе, как представителю в сфере педагогической профессии. «Профессионально-ценностное самоотношение педагога определяет, - по мнению О.Г. Бырдиной, его отношение к себе в профессиональной деятельности, а именно к процессу своего профессионального становления и самореализации в пространстве и во времени профессиональной деятельности, воссоздающей путем интеграции различных аспектов своего «Я» в профессии (Я - действующее, Я взаимодействующее, Я - живой организм, Я - существующее, Я - осуществляющееся), переходящих в целостный образ «Я -профессиональное» [3, с. 537]. Основываясь на проделанном анализе, мы можем определить основные компоненты педагогического мастерства преподавателя, необходимые ему для решения поставленных перед ним профессионально-педагогических задач (Рис. 1).

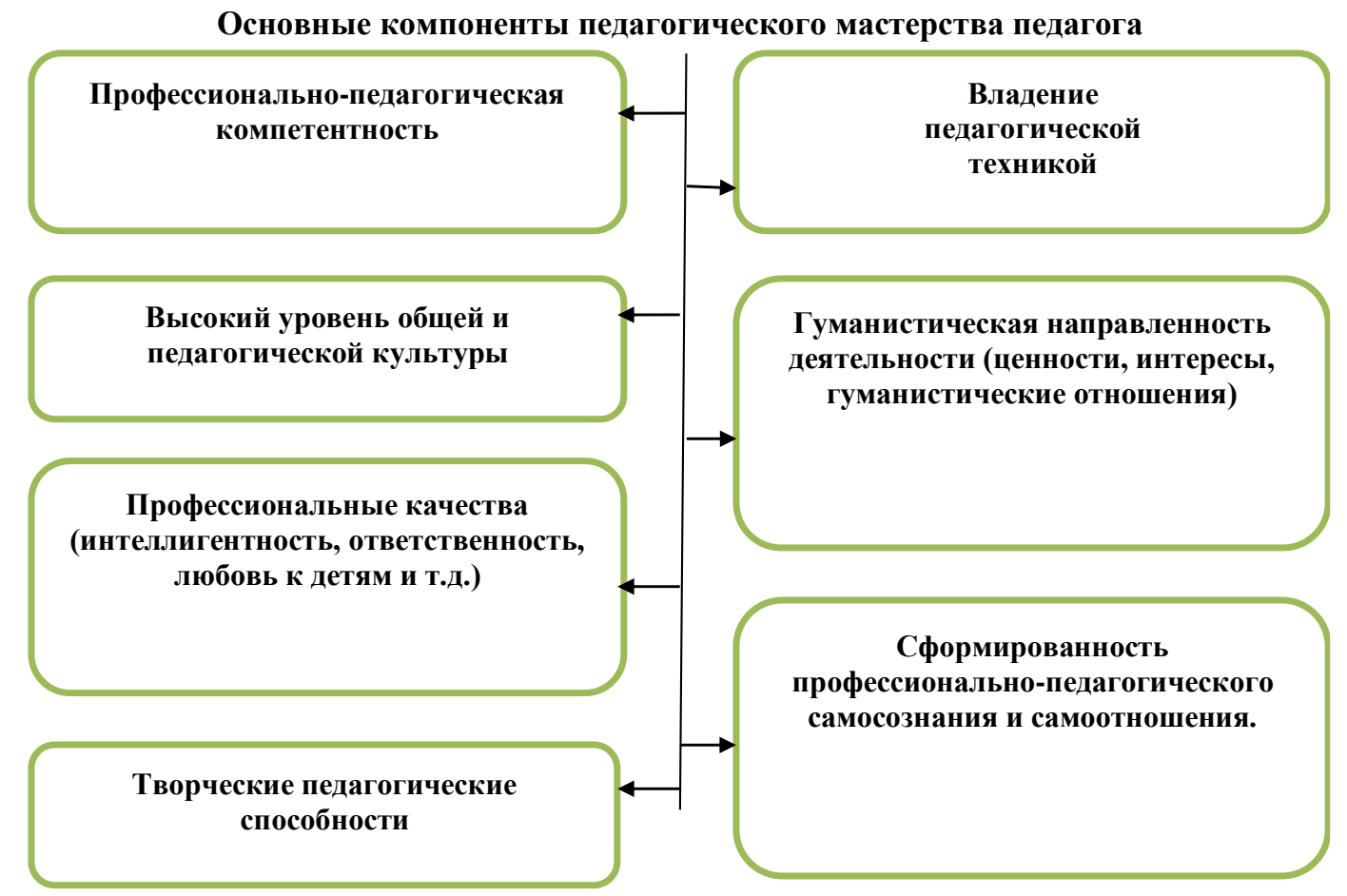

Puc. 1.

В настоящее время в учебной практике большое внимание уделяется именно творческим педагогическим способностям педагога, поскольку именно они помогают ему применять в постоянно меняющихся условиях свои профессиональные знания и умения. Творческая деятельность преподавателя предполагает особую гибкость мышления, генерацию разнообразных идей, рефлексию, а также стремление к совершенствованию. 
Необходимо также привести мнение исследователя Л.Ф. Спирина, который в отношении понятий «педагогическое мастерство» и «педагогическая задача» предполагает их неразделённость, утверждая следующее: «...дорога к профессиональному мастерству решения педагогических задач - непростая. Чем выше ступеньки умений, тем больше в личной умелости каждого учителя научного знания, на основе которого находятся оптимальные (или близкие к ним) решения» $[8, \mathrm{c}$. 105]. В.А. Сластёнин в свою очередь предполагает, что «под педагогической задачей... следует понимать осмысленную педагогическую ситуацию с привнесённой в неё целью в связи с необходимостью познания и преобразования действительности» [7, с.42]. Таким образом, педагогическое мастерство должно заключаться в поиске наиболее качественного и эффективного решения среди имеющихся, рациональном анализе задач с отбором необходимых решений.

Подводя итог, необходимо отметить, что педагогическое мастерство в решении различных педагогических задач разнообразного уровня сложности, также должно зависеть и от понимания и учёта преподавателем индивидуальных, социально-психологических и возрастных особенностей студентов. Начинающий, а значит не совсем опытный педагог, как правило, при решении педагогических задач намечает множество способов их решений. А уже более опытный педагог, являющийся мастером своего дела, не будет перебирать готовые варианты решений, а намечает свою особую программу действий, исходя из конкретных педагогических условий. Таким образом, профессиональное мастерство педагога, главным образом, должно состоять из его умения максимально применять свои теоретические и творческие возможности для наиболее продуктивного образования и воспитания студентов. Оценивать уровень педагогического мастерства педагога можно по достигнутым результатам, представляющим собой специфические изменения, произошедшие не только с самими студентами, но и в отношениях между студентами и педагогом.

\section{ЛИТЕРАТУРА}

1. Беспалько В.П. Слагаемые педагогической технологии. - М.: Педагогика, 1999. - С.52.

2. Бодалев А.А. Личность и общение. - М.: Международная. пед. академия 1995. - С. 69.

3. Бырдина О.Г. Позиционный подход к пониманию профессионально-ценностного самоотношения будущего педагога. // Молодой ученый, № 11(58), 2013. - С. 576.

4. Сластёнин В.А. и др. Педагогика: Учеб. пособие для студ. высш. пед. учеб. заведений / В.А.Сластёнин, И.Ф.Исаев, Е.Н.Шиянов. - М.: Издательский центр «Академия», 2002. - 272 с.

5. Сластенин В.А. и др. Педагогика: Учеб. пособие для студ. высш. пед. учеб. заведений / В.А.Сластенин, И.Ф. Исаев, Е.Н. Шиянов. - М.: Издательский центр «Академия», 2002. - С. 498.

6. Сластёнин В.А. Педагогика: Учебное пособие / В.А. Сластёнин, И.Ф. Исаев, Е.Н. Шиянов / Под ред. В.А. Сластёнина. - М.: Академия, 2007. - С. 337.

7. Спирин Б.Ф. Педагогика решения учебно-воспитательных задач. - К.: КГУ, 1994. - С. 105. 